\title{
Embedding Entrepreneurial Knowledge in Vocational College Curriculum: A Case Study of the Competency of TVET Instructors
}

\author{
Muhd Khaizer Omar*, Khamsiah Ismail, Arnida Abdullah, Suhaida Abdul Kadir \\ and Rosnani Jusoh
}

Faculty of Educational Studies, Universiti Putra Malaysia, 43400 UPM Serdang, Malaysia

\begin{abstract}
Entrepreneurial knowledge is important and it has been adopted in numerous curriculum and subject matters. Even though the embedding of the entrepreneurship syllabus in the curriculum might be able to enhance the knowledge of the students and subsequently trigger their interests in business, very often students would forget about it once they graduated from the program and fail to put their entrepreneurial knowledge to use. One of the common postulations was the lack of effective teaching by the teachers. Based on this assumption, a case study was conducted to explore the competency requirement of teachers related to the teaching of entrepreneurial-based knowledge and to investigate the process of teaching and learning entrepreneurship curriculum in the classroom settings. A semi-structured interview was conducted to the 7 informants. The informants were chosen using purposive sampling from the selected vocational colleges ( 3 instructors, 3 students, and 1 director). In-depth and constant comparative analysis was utilized to validate the

ARTICLE INFO

Article history:

Received: 13 November 2020

Accepted: 11 March 2021

Published: 14 April 2021

DOI: https://doi.org/10.47836/pjssh.29.S1.06

E-mail addresses:

khaizer@upm.edu.my (Muhd Khaizer Omar)

khamsiahikhamsiah@gmail.com (Khamsiah Ismail)

arnidaa@upm.edu.my (Arnida Abdullah)

suhaida@upm.edu.my (Suhaida Abdul Kadir)

rj@upm.edu.my (Rosnani Jusoh)

*Corresponding author

themes. We triangulated the narratives along with five other sources of data, including note-taking via observations, document analysis of lesson plan, curriculum content, policy, and guidelines. NVIVO software was used to organize the narratives and guide the thematic analysis findings. The findings demonstrated that entrepreneurial competency is important for the engineering TVET instructors to pass on the necessary entrepreneurial skills to students. In view of the latest trends in business and
\end{abstract}

ISSN: 0128-7702

e-ISSN: 2231-8534 
marketing strategies and wide application of gig economy, the range of competency in entrepreneurial skills identified in shaping the future orientation of entrepreneurial fields.

Keywords: Entrepreneurial competency, instructor, technical and vocational education and training (TVET), vocational college

\section{INTRODUCTION}

The constantly evolving economic trends have ushered in a new era of product purchasing and consumption for the consumers. Changes in the trends and methods of doing business especially during COVID-19 have called for a renewed and improved understanding of the consumer's behavior (Eriksson \& Stenius, 2020). Following this, the various strategies to fulfill this requirement were defined as the gig economy by the stakeholders. With the growth of the gig economy and its influence on mainstream businesses, entrepreneurs must strategize new and flexible ways of doing business. It is vital to empower the younger generation for them to seize the opportunities and to be independent entrepreneurs rather than job seekers (Omar et al., 2011). By being an entrepreneur, they can also create jobs for others to boost the economy and to safeguard the well-being of others. For example, the United States has witnessed a significant transformation in which people are no longer tied to specific jobs with certain companies but rather they have moved on to a more flexible and independent work arrangement that allows a higher degree of freedom and pleasure (Friedman, 2014).

In response to this new landscape in the digital economy environment, creativity in creating businesses and job opportunities is vital (Barile, 2017). The increasing trend of digital connectivity through marketing platforms continues to pique the interests of people on various products. Furthermore, digital technology mediates the networking between the people and entrepreneurs, thus creating different elements in marketing (Thompson, 2019). In view of the rapid development of the digital platform especially in entrepreneurial fields, a structured curriculum should be incorporated. It is also equally important to have teachers who are experienced in teaching those elements to ensure the best outcomes.

From the perspective of the Technical and Vocational Educational and Training (TVET) field, the entrepreneurial curriculum has long been imposed in its teaching and learning (Ibrahim et al., 2015). The process of teaching entrepreneurship knowledge is included in specific courses or embedded through class activities and programs. Therefore, TVET instructors play a vital role in planning and implementing these entrepreneurship elements in their teaching and learning procedures (Dahalan et al., 2018). A TVET instructor is a trainedteacher with the industrial background as a result of their previous working experience in related fields (Affandi et al., 2020). The aim of TVET is to produce future graduates who are capable of joining the 
workforce immediately upon completion of the program (Omar et al., 2011). To accomplish this objective, TVET Malaysia strives to achieve the status as an educational hub of excellence in TVET teaching by ensuring that highly competent, confident, and credible TVET teachers (Alazzam et al., 2012; Kamaliah et al., 2018; Ramlan et al., 2017) are available to empower the students and to produce quality graduates from the program.

The Malaysian Ministry of Education (2013) aims to produce competent vocational college graduates to meet the needs of skilled and semi-skilled workers in the industrial sectors. The target set by MOE was to have at least $70 \%$ of the graduates joining the workforce of the relevant training field, another $20 \%$ pursuing higher degree education in related fields, and lastly, $10 \%$ of them taking up entrepreneurship (TVET Division, 2012). In order to achieve this, vocational college teachers must be the ones with the highest quality, competency, responsibility, and professionalism in performing their duties. Idris and Hamzah (2013) stated that the quality of the teaching could be only safeguarded by excellent levels of leadership competence, intrapersonal, and interpersonal skill. Furthermore, another study reported that TVET instructors must gain the necessary experience before they could develop the knowledge needed to deliver better teaching and learning experiences to the students (Chua \& Jamil, 2012a). This finding was further strengthened by Said et al. (2016) who pointed out that the quality of teaching depended on the competency of the subject matter, the teaching method, and good management in the preparation of teaching materials.

However, there are certain issues related to the quality of TVET teachers (Grosch, 2017; Omar et al., 2020). These issues have been addressed in conferences and seminars and the discussion pointed towards a lack of quality among TVET teachers. This was also echoed in the works of Iwu et al. (2019) and González Moreno et al. (2019) who studied on different levels of conventional teachers, and Mohd Jamil (2007) as well as Abd. Aziz (2007) in TVET stream found that the competency component of entrepreneurship teaching was still lacking. Such incompetence projects a negative image on the TVET students and institutions in Malaysia (Affandi et al., 2020; Chua \& Jamil, 2012b). In a recent study, Omar et al. (2020) reported similar findings whereby TVET instructors in the engineering field had moderate levels of knowledge, attitude, and practice in the field of entrepreneurship. In view of these issues, Abdullah et al. (2019) highlighted the need to improve the level of entrepreneurial teaching in engineering courses at vocational colleges so that the aspirations of the $21^{\text {st }}$ century education can be successfully achieved.

\section{Literature Review}

In the literature, the researchers have outlined a clear definition of entrepreneurial competence to avoid confusion with other elements of competency. Entrepreneurial competency can be defined 
as the knowledge, skills, and personal characteristics possessed by individuals to help them carry out their responsibilities in the field of entrepreneurship or business (Abd. Aziz, 2007). In addition, Al Amin, (2013) emphasized the significance of the entrepreneurial component and how it should be well-taught by instructors to create the necessary awareness so that the entrepreneurial subject matter could be mastered by the students before entering the workforce.

\section{Model Human Resource Development (HRD) Practice}

The Human Resource Development (HRD) Model defines that a successful organization must have four key competencies, namely technical skills, interpersonal skills, intellectual abilities, and business skills. Based on this notion, all the aforementioned competency traits are very much needed in an education institution for the teachers and students to polish their technical abilities and expertise. It also highlights the importance of entrepreneurship or business skills for TVET engineering lecturers in educating and guiding vocational college students. Figure 1 shows the HRD Model by Mc Lagan (1989).

As this study was conducted for engineering TVET instructors at Vocational college, the theory was particularly relevant to the context of this study. All the components of the HRD Model were appropriate and consistent with this study. Specifically, the TVET instructors need to possess technical, interpersonal, intellectual, and entrepreneurial skills to systematically and professionally produce competent graduates who can meet the market demands in the workforce. Mohd Jamil (2016) also

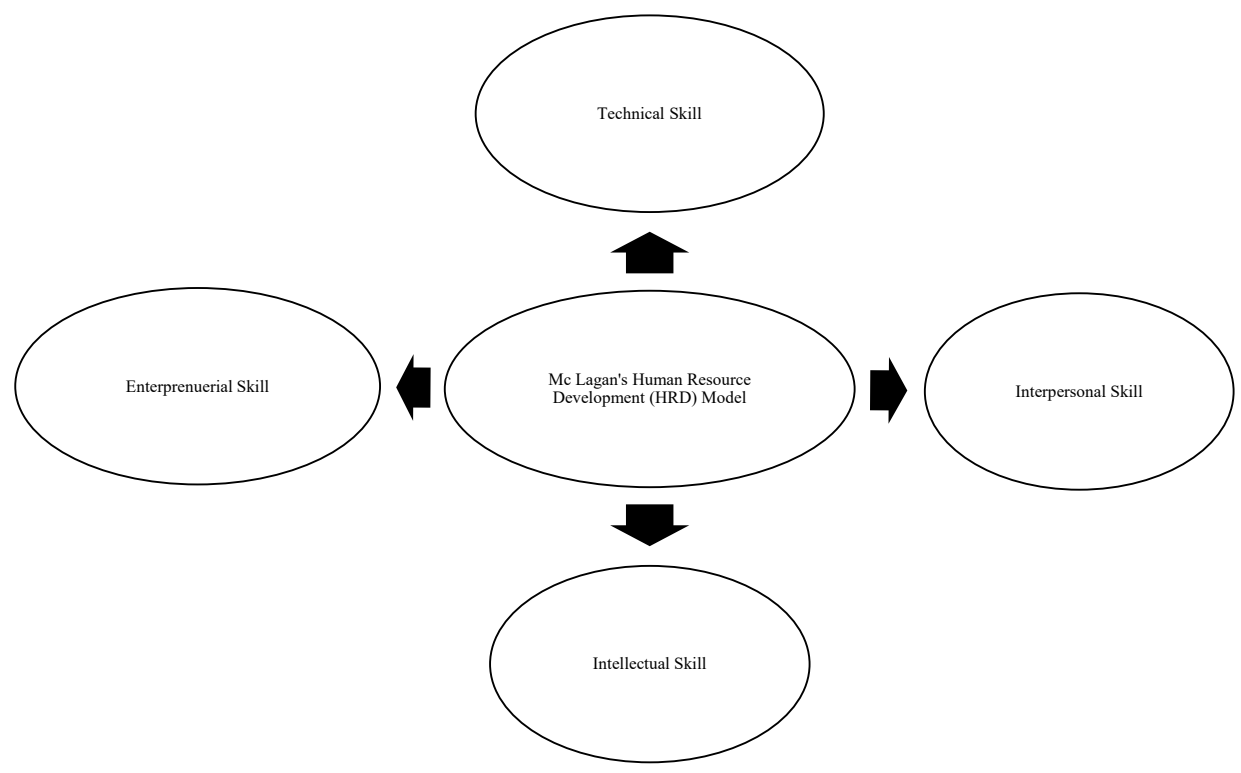

Figure1. Mc Lagan's Human Resource Development (HRD) model (1989) 
used the HRD Practice model in his study and emphasized that TVET instructors needed to have all four components of competency in this model. This was also in line with the study by Khalil (2017) that revolved around the development model of teacher professionalism in Malaysia.

\section{Malaysian Standard Teacher Model (MSTM) (2009)}

The MSTM is a reference model used by all teachers in Malaysia that emphasizes the need for instilling values and professionalism in the teaching of skills and knowledge. TVET teachers are expected to provide the best education to produce highly qualified graduates in the respective fields. Therefore, it is imperative for teachers to emphasize good practices, values, and attitudes as well as to impart knowledge on all the relevant fields. The MSTM model should be adopted to produce highly competent, good quality, and excellent teachers. Figure 2 shows the MSTM as depicted in the Ministry of Education (2009).

In the context of this study, the MSTM Model is a suitable reference as it forms the basis for all instructors, including TVET instructors in the engineering stream of vocational colleges (Sharif et al., 2017). Furthermore, it is a comprehensive teaching model that encompasses professional values and practices, instructional and pedagogical skills, as well as the knowledge required of

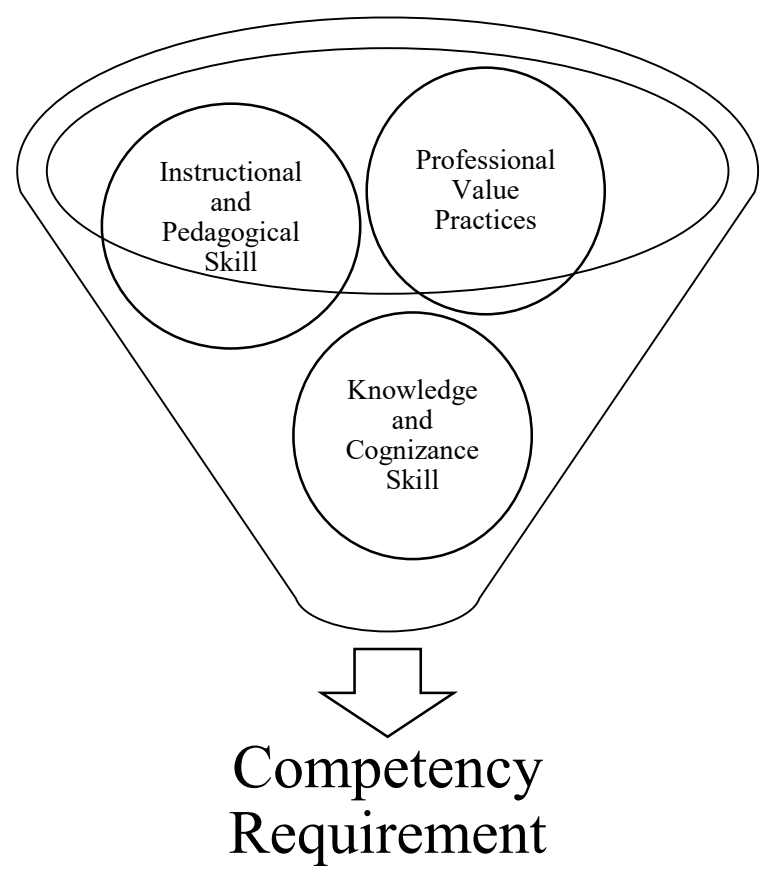

Figure 2. Model standard guru Malaysia (MSTM)

Source: Ministry of Education (2009) 
teachers. As shown by Tamuri et al. (2012), the model is a basic guide for teacher preparation. In addition, Idris and Hamzah (2013) reported that the model was useful as a reference guide in producing quality instructors. By following this model, TVET instructors will be more competent in terms of knowledge and understanding, more skillful in the teaching and learning process, as well as more focused on the vital professional values required to produce a generation of students who are motivated and competent in entrepreneurship (Salleh \& Sulaiman, 2020).

\section{The Importance of Entrepreneurial Competency}

In a study conducted by Abd. Aziz (2007) and Mohd Jamil (2007), TVET instructors at the polytechnic colleges and public institutions of higher learning in Malaysia listed entrepreneurship as an important component in the teaching domain. Subsequently, Mohd Jamil et al. (2015) also emphasized that the entrepreneurial component was very important to be instilled among engineering students in the TVET institutions in Malaysia. The motivation from the instructors plays an important role in the process of producing students who are passionate about entrepreneurship (Mohd Mustafa et al., 2013). The relevant field experience and the knowledge and skills in entrepreneurship can help them to meet the requirements of the industry. To achieve that, students need to be exposed to the basics of entrepreneurship in order to motivate them to sustain their interest in entrepreneurship and fundamental requirements of the business.

In the modern world today, there are various opportunities available especially in the field of marketing. TVET graduates should be encouraged to venture into the high potential entrepreneurial field (Nasharuddin \& Harun 2010). In a recent study, Halberstadt et al. (2019) emphasized that a positive role by the instructors in this area of entrepreneurship could create creative and innovative students. They would also be highly competitive when they entered the real world upon graduation. Mohd Jamil (2016) also argued that entrepreneurship was a component of generic competence that all TVET instructors must master in order to effectively produce excellent human capital that met the current needs.

\section{Research Objective}

This study aimed to explore the elements of entrepreneurship competency among engineering TVET instructors at vocational colleges and the teaching methods used by them to impart entrepreneurship knowledge to students.

\section{Research Questions}

This study was conducted to answer the following research questions:

i. What are the entrepreneurial competency elements required by the engineering TVET instructors in vocational colleges?

ii. How are the entrepreneurial knowledge elements being imparted to vocational college students? 


\section{MATERIALS AND METHODS}

Given that this study was related to previous studies on the building process of teachers' competence, a case study was used as the selected study approach to delineate the concerns about teacher competency and competency gap among TVET instructors that might have negatively impacted the teaching and learning process of TVET graduates. By using the case study approach, the researcher aimed to explore the interaction between informants with regard to the desired significant competency indicators among instructors, the comparison with existing competencies, and how such competencies could be instilled in the student to be mastered by them. As suggested by Yin (2014), case studies are commonly used in qualitative research to answer the questions of how and why. This was similar to Lebar (2007) who reported that the case study was qualitative research aimed at exploring, interpreting, and developing an in-depth understanding of a case. Furthermore, Yin (2014) also suggested that a qualitative case study could be applied if the researcher was studying a contemporary case or new phenomenon rather than a historical study. In this study, the researchers explored the information provided by informants when addressing in-depth questions. Following that, the findings of their research were enriched with their teaching experience on competencies. The researcher also obtained information from various other sources such as interviews, observations, audio-visual materials, documents, and reports. The use of information was in line with Creswell's (2013) recommendation who emphasized that case studies required researchers to carry out detailed studies, collect in-depth data, and engaged multiple sources of information.

\section{Informants and Research Context}

The study location was the three vocational colleges in the Klang Valley, namely Sepang Vocational College, Kajang Vocational College, and Sungai Buloh Vocational College. They were chosen because of their close proximity to industrial areas.

Purposive sampling was applied in this study. The selection criteria for informants included being teachers and directors for more than 10 years or final year students in diploma and engineering courses with Malaysian Skills Certificate Levels 1 and 2. Furthermore, the selected informants were also committed and experienced in this field of study, so that they were able to share information voluntarily and sincerely. The informants were selected following the suggestion of the first informant who provided the names of other personnel deemed suitable for this study. Upon selection, the informants consisted of three teachers who were experienced instructors in the engineering course, three final year engineering students who were undergoing On Job Training in the industry, and one director with a background in education and experience in engineering.

In this study, a semi-structured in-depth interview was conducted with the informants using a set of structured questions as an 
interview protocol. The data was further strengthened with participant observation activities and document analysis. During the interview, the researcher first established a good rapport with the informants before addressing the questions so that the data obtained would be more meaningful and of good quality.

\section{Data Collection}

In this study, semi-structured interviews were used for data collection. This method was chosen because it was more balanced and appropriate in exploring the informant's feedback in the narrative form (Seidman, 2013). Open-ended and probing questions were used to obtain further information. Face-to-face interviewing techniques were applied to collect data that could provide detailed experience and information (Rubin $\&$ Rubin, 2012). Participants with a longer period of experience and expertise in the field would be able to generate more meaningful information (Seidman, 2013).

A set of interview protocols was developed for the data collection. Interview guides were used to uncover more in-depth answers to the research questions in this study. The interview guide was essential to ensure that a smooth and well-organized interview process (Seidman, 2013). Once the data had been collected through the interview process, the researcher transcribed the audio-recorded data using computer software. Each word and specific sound from the participant's answer during the interview session was transcribed without any alteration.

\section{Data Analysis}

The interview transcripts were read repeatedly by the researchers to gain detailed insights to the answers so that they obtained a clear understanding of the meaning of each transcript. The researcher then attempted to make the meanings consistent with the actual research questions of the study. The process of encoding the data was done right after the transcription process. Encoding is a process of categorizing or giving themes to something contained in a transcript or text (Creswell \& Poth 2018). The encoding process consists of three processes: open coding, vertical code (axial coding), and selective coding. Researchers used NVIVO software to perform data encoding processes to find the meaning of keywords or phrases that would help in answering research questions. According to Creswell (2013), there are eight strategies that can be used to increase the validity and reliability of a study. However, in this study, three strategies were used, namely member checking, triangulation, and peer review. The themes that emerged from this study was formed based on the aforementioned strategies to ensure trustworthiness and credibility of the qualitative findings.

\section{RESULTS}

The findings were derived from the narratives of the instructors, director, and students. It also involved the triangulation process of document analysis and note-taking during observation. It is fair to note that the observation describing the entrepreneurial aspect was rarely emphasized to the students 
during the teaching and learning process. In addition, analysis of documents was also carried out by reviewing the teaching and instructional files of the teachers. The following subsections outline the study findings based on the themes derived.

\section{Excerpts from Narratives}

"When teaching, teachers will always show business knowledge to the students in the class and teachers will always tell you about the experiences of senior students from the vocational college who were successful in business." (Student \#2-interview session \#1)

"For business students, they must have a degree of knowledge in business management or entrepreneurship. So, teachers should play a role in delivering that knowledge. Therefore, the instructors must first master all these competencies in order to teach, educate, and guide the students. The instructors must also be knowledgeable to be able to provide motivation to the students." (Instructor \#1-interview session \#1)

Student 2 stated that the teachers possessed entrepreneurial knowledge. This was acknowledged by Instructor 1 who emphasized that teachers must be competent in the entrepreneurial aspect and to always provide motivation to students. However, the director argued that TVET instructors in vocational colleges had only basic knowledge in entrepreneurship and thus, they still needed training courses to improve their knowledge and skills in entrepreneurship.
"Instructors may need to take courses in enhancing their knowledge and skills to be in line with the latest emerging technologies in the market, including the field of entrepreneurship so that students are more exposed to and aware of the complexities of their business. This can also attract those who have aspirations of starting a business." (Director-interview session \#1)

Furthermore, the director explained that the instructors were only exposed to the basics of entrepreneurship and thus, the students had to work on their own to find more experiences.

"There are also vocational college graduates who became entrepreneurs and started businesses such as car service shops and air-conditioning service companies around Hulu Langat. But, there were not many of them because the other might have less exposure... Vocational college instructors may be able to provide the basic exposure to the student, but eventually, it still depends on the student's own ability and courage." (Director-interview session \#1)

This was supported by the statement of Instructor 2 who claimed that he had very limited basic knowledge in entrepreneurship. Furthermore, he went on to explain that not many students were interested in taking up the risk of doing business. However, he would try to be as supportive as he could if the student was really interested.

"Not many students are truly interested in taking the risk of a business. However, some students who came from a background of family business have some experience 
in this field. Therefore, they would be more inquisitive about entrepreneurship and business. So, I will help with what I can help. If I am not sure, I'll refer them to senior students who are already running businesses." (Instructor \#2-interview session \#2)

Similarly, Instructor 3 was also very frank in admitting that he was not wellversed and skillful with regard to business knowledge. As he only had basic knowledge, he suggested some alternatives to help the students at this vocational college.

"I'm not very smart, but I help in any little ways that I can. It doesn't matter if you want to tell a story and explain your business, as long as the basics of the business are there and they can help the students to make some money. I'm encouraged to share my knowledge too, but I think the information I have about this business is pretty limited. It is important to invite experts in the field of entrepreneurship to hold a special briefing to give exposure to all final year students."

\section{(Instructor \#3-interview session \#1)}

"In fact, entrepreneurship was only taught and emphasized during core ability (CA) teaching and we were assisted by academic teachers through their own modules. So, we just emphasize soft skills in the workshops and browse through apps used for security and collaboration, that's it." (Instructor \#1-interview session \#2)

Five themes were developed based on the thematic analysis technique. The themes specifically elaborated from the narratives and meaning making process of the respondents. The excerption as depicted earlier was compiled prior to triangulation process that involves document analysis, member checking and peer review process to ensure the findings is credible and genuine. The themes are as stated:

Theme 1: Poor performance level of entrepreneurship competency among teachers

The theme suggested that the teacher's performance in terms of entrepreneurship competency was weak and under expectation. This was also associated with low levels of enthusiasm and motivation among teachers. The feeling of inferiority might also lead to excessive stress and thus cast a negative impact on the teachers. Their day-to-day tasks of delivering the teaching and learning process in the workshop as well as their responsibilities as part of the administration would be affected. As a result, the TVET division in the vocational colleges might suffer from a lack of qualified instructors. This could further complicate the aim of the TVET division to have $20 \%$ of their graduates pursuing entrepreneurship. Therefore, it is vital for all stakeholders to seek solutions to enhance teacher competencies in entrepreneurship. Modifications in teaching methods and techniques such as the alternatives suggested in this study can help to avoid the negative implications that may arise if no efforts are taken to improve the professional level of entrepreneurship among TVET engineering faculty instructors in vocational colleges. 
Theme 2: Low effectiveness of teacher quality improvement programs

Various programs had been implemented to enhance the quality of TVET instructors. Some were conducted by the TVET division and vocational college while others were in collaboration with other institutions or the industry. Collaboration programs can avoid the need to spend a relatively high cost for non-vocational college TVET trainers with no previous experience in the relevant workshops and industry. The findings from this study, however, suggested that some of these efforts still failed to meet the purpose of the programs. Therefore, further efforts must be undertaken by the involved parties to resolve this problem. They must take greater initiative to organize more programs that focus the weaker areas such as entrepreneurial competency for TVET engineering faculty.

\section{Theme 3: Low motivation of teachers}

The study also showed that some of the TVET vocational college instructors were aware of their weaknesses and shortcomings. They were concerned about not being able to meet the needs of everyone and ended up feeling alienated, unappreciated, and even overlooked by their peers. Over time, their motivation would decrease and they would lose interest to further develop their competencies. Therefore, it is important for the vocational colleges to design appropriate Career and Professional Development (CPD) programs to boost their self-esteem and motivation in the field of entrepreneurship. With the proper support, the instructors will be able to carry on with the teaching and learning process comfortably without having to exhaust their energy and time to look for ways to complement the deficiencies in their competence-related knowledge.

\section{Theme 4: Low levels of achievement and motivation among students}

In addition, to produce knowledgeable and skillful students, vocational college instructors need to equip themselves with the necessary components of competency. As evidenced in this study, the weaknesses and shortcomings among the instructors would be a barrier for them to provide the necessary knowledge and skills about entrepreneurship. Thus, all the involved parties need to find a way to solve the problem to enable the students to achieve good and competent knowledge, skills, and attitudes in the field of entrepreneurship.

\section{Theme 5: Failure to meet industry requirements}

Vocational colleges aim to provide students with the necessary skills to enhance their employment opportunities. Therefore, graduates from vocational colleges would be expected to have bright employment opportunities if they can meet the industry requirements. However, this study highlighted several weaknesses in the competency skills, especially the entrepreneurial element. When teachers are weak in communicating entrepreneurshiprelated information effectively, this can cast a negative effect on vocational college 
graduates. Those who are lacking of entrepreneurial knowledge and skills will be shunned by the industry. Eventually, the industry may lose confidence on vocational college graduates due to lack of their workforce competency especially on entrepreneurial knowledge and skills. Therefore, the relevant stakeholders must address the existing deficiencies and weaknesses highlighted by this study for the benefit of all the directors, instructors, and students involved in TVET.

\section{DISCUSSION}

The findings revealed a lack of information and preparation by instructors in terms of entrepreneurial skills. It is important for TVET faculty instructors at vocational colleges to be competent in entrepreneurship skills. However, in this study, even the directors and teachers themselves acknowledged that the entrepreneurship competency among the instructors themselves was of a modest level. Most of the teachers were inexperienced and had only basic knowledge and skill in entrepreneurship. Nevertheless, they were willing to help students who were interested in the field of entrepreneurship. Therefore, even though the lack of competence of the teachers is an obstacle, they can still find a solution by seeking the help of stakeholders from numerous agencies for example curriculum development unit, industrial player, and successful entrepreneur to address their students' questions.

The development of a clear theory can be traced to the HRD Model that includes interpersonal skills, intellectual skills, entrepreneurial skills, and technical skills. The entrepreneurial elements of the competency component are also in line with the entrepreneurial skills in the HRD model, whereby the TVET instructors in the engineering faculty at vocational colleges must implement vocational college-based teaching and learning curriculum. This includes on-job training (OJT) assessment to ensure they comply with the standards set by the relevant parties before they can be recognized by the Malaysian Qualification Accreditation (MQA) and Jabatan Pembangunan Kemahiran (JPK). While the technical and vocational education system in the vocational colleges is well established, ongoing efforts need to be streamlined to expand the TVET curriculum to better meet the latest needs of the industry. So far, the HRD Model has been very consistent and accurate in showing the clear link between acquiring and applying the necessary components of competency for TVET instructors in vocational colleges.

As mentioned above, the Malaysian Teacher Standard Model (MTSM) involves the incorporation of professional values, teaching and learning skills, as well as knowledge and understanding in daily teaching. Thus, the model is closely linked to the competency of TVET instructors in vocational colleges. It is undeniable that a good teacher should fulfill all the features in the MTSM model. The explanation about the competence of professional pedagogy is clearly in line with the teaching and learning skills stated in the MTSM model. 
Similarly, professional personality, values, and ethics can also be categorized in line with the practice of values in the MTSM model whereas professional components of social processes, management, knowledge, and skills can be categorized under the knowledge and understanding part of the MTSM model. All of these components of competence must co-exist and be applied by the teachers to fulfill their responsibilities as high quality and excellent teachers. The results of this study were in line with Abu Baser et al. (2016) who stated that the three levels in the MTSM model, namely practice of professional value, knowledge, and understanding, as well as teaching and learning skills, were crucial in the development of competent and excellent teachers.

Currently, the entrepreneurial competence of the instructors does not meet the actual needs and expectations (Abdullaeva et al., 2020; Panfilova et al., 2019) and no standardise tools to asses (Bolzani \& Luppi 2020). As such, the competency of all the vocational college teachers needs to be further strengthened to improve the quality and excellence of TVET vocational college education and institutions in Malaysia. This can be achieved by increasing the awareness of the importance of the competency development process (Omar et al., 2011). Furthermore, various initiatives need to be taken to ensure that teachers' competencies in the field of entrepreneurship can be developed so that the students can reap the benefits. For example, entrepreneurship courses to disseminate knowledge and basic skills among the students can be organized to attract students towards the field of entrepreneurship (Abd Rahman et al. 2015; Ibrahim, et al., 2015).

In order to achieve these goals and objectives, it is imperative for teachers to gain a deeper understanding of the guidelines presented in this study. The deficiencies and inadequacies of the instructors must be identified so that the necessary elements can be added to enhance their competencies. Based on the findings of this study, it is hoped that instructors will be able to receive the vital guidance to benchmark their respective competency levels before taking further steps in the right direction to account for any lack of competence.

Moreover, efforts should be made to engage highly qualified and skilled experts in the field of entrepreneurship to deliver more effective teaching and learning process to enhance students' knowledge and skills. Ultimately, this can produce successful and skillful students who are truly interested and self-reliant in establishing their entrepreneurial journey. In today's business world, it is possible to achieve the aspirations of the government for at least $20 \%$ of vocational college graduates to kickstart their businesses after graduation if the necessary steps are taken.

To achieve the target, relevant programs such as entrepreneurship courses and workshops as well as in-service training courses should be planned, especially for TVET teachers in the engineering faculty. Apart from that, the vocational 
colleges can also organize activities such as in-service training program by engaging senior instructors to share their experience with TVET teachers. In addition, external experts such as renowned business owners or entrepreneurs in Malaysia can be invited to the colleges to deliver motivational talks and to disseminate their business knowledge and skills to the TVET engineering faculty. Motivation from successful business entrepreneurs is essential to spark interest among the students for them to open their minds to acquire the necessary knowledge and skills in entrepreneurship. Last but not least, business-related programs such as business carnivals or business month can be held in the organization. Students can be tasked to organize these activities with the help of vocational college instructors to develop their interests. Additionally, the business department can collaborate with the engineering department to organize programs with common knowledge and experience to benefit students in both departments.

\section{CONCLUSION}

In line with the goals of the Malaysian Education Development Plan 2013-2025, the need for competent, confident, and knowledgeable experts in the field of entrepreneurship calls for the necessary steps to address the competency gap among the TVET instructors. Based on the study findings, all the informants including director, teachers, and students agreed that entrepreneurship competency is highly needed by the TVET instructors in vocational colleges. However, our study showed that the level of entrepreneurial knowledge and skills are still questionable among instructors. The current situation regarding the COVID-19 pandemic could also challenge the instructors to deliver entrepreneurial knowledge effectively. Therefore, the teaching of TVET entrepreneurship in vocational colleges should be improved through the several strategies identified in this study. Moreover, the value-added of the current situation needs to be studied further.

\section{ACKNOWLEDGEMENT}

We would like to express our sincere gratitude to the respondents who provided cooperation in this study.

\section{REFERENCES}

Abd Rahman, S. S., Muhammad Sabri, M. F. \& Nadzri, S. (2015). Self-entrepreneurship competence among students taking entrepreneurship courses at university. [Paper presentation]. Proceeding of the 2nd International Conference on Management and Muamalah 2015 (2ndICoMM) (pp. 372 384). Selangor: International Islamic University College Selangor.

Abd. Aziz, M. S. (2007). Designing the national standard framework for TVET teacher / instructor coaching programs [Unpublished Masters' thesis]. Universiti Tun Hussein Onn Malaysia.

Abdullaeva, A. M., Maigeldieva, S. M., Bukharbayeva, A. Z., Talapbayeva, G. E., \& Mukhanova, A. (2020). Psychological and Pedagogical Foundation in the Formation of Entrepreneurial Competence of Future Teachers. Talent Development \& Excellence, 12(1). Retrieved 
from https:/www.iratde.com/index.php/jtde/ article/view/619

Abdullah, Z., Hoque, K. E., Ramlan, N. H., \& Shafee, S. (2019). Designing the structural model of TVET lecturers' professionalism and generic skills based on an empirical study in Malaysia. SAGE Open, 9(3). doi: $10.1177 / 2158244019861456$

Abu Baser, J., Mohd Suhaimi, N. S., Othman, H., Hasan, A., Rahim, M. B. \& Nur Yunus, M. F. A. (2016). Designing Malaysian teachers' standard in design and technology teacher preparation program [Unpublished Master's thesis]. Universiti Tun Hussein Onn Malaysia.

Affandi, H. M., MK, M. F., Lazaro, M. H., Khamis, A., Abas, N. H., Sallehuddion, M., \& Yunus, F. A. N. (2020). The development of a generic competency portfolio for Malaysian TVET construction graduates. Journal of Technical Education and Training, 12(3), 143-153. doi:10.30880/jtet.2020.12.03.015

Al Amin, M. H. (2013). Inculcation of entrepreneurial skills among mechanical engineering students in UTHM [Unpublished Masters' thesis]. Universiti Tun Hussein Onn Malaysia.

Alazzam, A., Bakar, A. R., Hamzah, R., \& Asimiran, S. (2012). Effects of demographic characteristics, educational background, and supporting factors on ICT readiness of technical and vocational teachers in malaysia. International Education Studies, 5(6), 229-243. doi:10.5539/ies.v5n6p229

Barile, N. (2017). Branding, self branding, making: the neototalitarian relation between spectacle and prosumers in the age of cognitive capitalism. In M. Briziarelli, \& E. Armano, (Eds.), The spectacle 2.0: Reading debord in the context of digital capitalism (pp. 151-166). University of Westminster Press

Bolzani, D., \& Luppi, E. (2020). Assessing entrepreneurial competences: Insights from a business model challenge. Education + Training. doi: 10.1108/ET-04-2020-0072

Chua, J. H. \& Jamil, H. (2012a). The effect of field specialization variation on Technological Pedagogical Content Knowledge (TPACK) among Malaysia TVET instructors. The Malaysian Online Journal of Educational Technology (MOJET). 2(1), 36-44.

Chua, J. H. \& Jamil, H. (2012b). Factors influencing the Technological Pedagogical Content Knowledge (TPACK) among TVET instructors in Malaysian TVET Institution. Procedia Social and Behavioral Science 69(2012), 1539-1547. doi: 10.1016/j.sbspro.2012.12.096

Creswell, J. W. (2013). Research design: Qualitative, quantitative, and mixed method approaches (4th Ed.). SAGE.

Creswell, J. W., \& Poth, C. (2018). Qualitative inquiry and research design: Choosing among five approaches: International student edition. (4th Ed.). SAGE.

Dahalan, D., D’Silva, J. L., Ismail, I. A., \& Mohamed, N.A. (2018). Entrepreneurial mindset among students of technical and vocational education and training (TVET) institutions in Malaysia. Journal of Social Sciences Research, 4(11), 303-311. doi:10.32861/jssr.411.303.311

Eriksson, N., \& Stenius, M. (2020). Changing behavioral patterns in grocery shopping in the initial phase of the COVID-19 crisis: A qualitative study of news articles. Open Journal of Business and Management, 8(5), 1946-1961. doi: 10.4236/ojbm.2020.85119

Friedman, G. (2014). Workers without employers: Shadow corporations and the rise of the gig economy. Review of Keynesian Economics, 2(2), 171-188. doi: 10.4337/roke.2014.02.03

González Moreno, Á., López Muñoz, L., \& Pérez Morote, R. (2019). The role of higher education 
in development of entrepreneurial competencies: Some insights from Castilla-La Mancha university in Spain. Administrative Sciences, 9(1), 16. doi: 10.3390/admsci9010016

Grosch, M. (2017). Developing a competency standard for TVET teacher education in ASEAN countries. Jurnal Pendidikan Teknologi dan Kejuruan, 23(3), 279-287. doi: 10.21831/jptk. v23i3.13418

Halberstadt, J., Timm, J., Kraus, S., \& Gundolf, K. (2019). Skills and knowledge management in higher education: how service learning can contribute to social entrepreneurial competence development. Journal of Knowledge Management, 23(10), 1925-1948. doi: 10.1108/ JKM-12-2018-0744

Ibrahim, W. N. A., Bakar, A. R., Asimiran, S., Mohamed, S. \& Zakaria, N. S. (2015). Impact of entrepreneurship education on the entrepreneurial intentions of students in technical and vocational education and training institutions (TVET) in Malaysia. International Education Studies, 8(12), 141-152. doi: 10.5539/IES.V8N12P141

Idris, N. H. \& Hamzah, R. (2013). The value of professionalism for prospective teachers based on the Malaysian teacher standards measurement (MTSM). Jurnal Teknologi, 60(2013), 31-37. doi: $10.11113 /$ jt.v60.1445

Iwu, C. G., Opute, P. A., Nchu, R., Eresia-Eke, C., Tengeh, R. K., Jaiyeoba, O. \& Aliyu, O. A., (2019). Entrepreneurship education, curriculum and lecturer-competency as antecedents of student entrepreneurial intention. The International Journal of Management Education, 43(1), 116-120. doi: 10.1016/j.ijme.2019.03.007

Kamaliah, S., Roslan, S., Bakar, A. R., \& Ghiami, Z. (2018). The effect of supervised work experience on the acquisition of employability skills among malaysian students. Higher Education, Skills and Work-Based Learning, 8(4), 354-364. doi:10.1108/HESWBL-05-2016-0028
Khalil, A. (2017). Designing model of the Malaysian Teacher Professional Development program [Unpublished Doctoral dissertation]. Universiti Malaya, Malaysia.

Lebar, O. (2007). Qualitative research: Introduction to theory and methods. Penerbit Universiti Pendidikan Sultan Idris.

Mc Lagan, P.A. (1989). The models. A volume in model HRD practices. American Society for Training and Development (ASTD)

Ministry of Education. (2009). Malaysia teacher standard. Kementerian Pelajaran Malaysia.

Ministry of Education. (2013). Malaysian blueprint 2013-2025. Kementerian Pelajaran Malaysia.

Mohd Jamil, M. R. (2007). Designing transnational standards framework for TVET instructor programs [Unpublished Masters' thesis]. Universiti Tun Hussein Onn, Malaysia.

Mohd Jamil, M. R. (2016). Designing a SkiVes training curriculum model for the engineering education program based on Work-Based Learning (WBL) [Unpublished degree thesis]. Universiti Malaya, Malaysia.

Mohd Jamil, M. R., Siraj, S., Hussin, Z., Mat Noh, N., \& Sapar, A. A. (2015). Application of Delphi fuzzy techniques to entrepreneurial element requirements for Malaysian Polytechnic Engineering lecturers. International Journal of Business and Technopreneurship. 5(1), 135-150.

Mohd Mustafa, U. A., Mohd Daud, S., Mohd Senon, M. \& Mohd Ismail, N. B. (2013, December 1). Career tendency as an entrepreneur among bumiputera students in the final year of the agricultural business diploma, Kolej Profesional Mara Beranang. [Paper presentation]. Graduate Research in Education Seminar (GREduc 2013). Selangor, Malaysia.

Nasharuddin, N. \& Harun. H., (2010). Entrepreneurial career aspirations among IPTA students. Jurnal Pendidikan Malaysia. 35(1) 11-17. 
Omar, M. K., Zahar, F. N., \& Rashid, A. M. (2020). Knowledge, skills, and attitudes as predictors in determining teachers' competency in Malaysian TVET institutions. Universal Journal of Educational Research, 8(3C), 95-104. doi: 10.13189/ujer.2020.081612

Omar, Z., Krauss, S. E., Sail, R. M., \& Ismail, I. A. (2011). Exploring career success of late bloomers from the TVET background. Education and Training, 53(7), 603-624. doi: 10.1108/00400911111171995

Panfilova, E., Demkina, O., Galichkina, M., Istomina, A., Latysheva, V., \& Teymurova, V. (2019). Learning models based on a real project in entrepreneurial education. Journal of Entrepreneurship Education, 22(2), 1-12.

Ramlan, N. H., Abdullah, Z. \& Hussin, S. (2017). General competency level of lecturer in construction technology, civil engineering vocational college, Ministry of Education Malaysia based on job grade and year of teaching experience. Jurnal Kepimpinan Pendidikan, 4(4), 39-55.

Rubin, H. J., \& Rubin, I. S. (2012). Qualitative interviewing: The art of hearing data (3rd Ed.). SAGE.

Said, R. R., Jamian, A. R., \& Sabil, M. A. (2016). The scope of knowledge and understanding of teaching and learning of Malay language among school improvement specialist coaches plus (SISC+). International Journal of Education and Training (InJET), 2(2), 1-9.

Salleh, K. M. \& Sulaiman, N. L. (2020). Reforming Technical and Vocational Education and Training (TVET) on workplace learning and skills development. International Journal of Recent Technology and Engineering, 8(5), 2964-2967. doi:10.35940/ijrte.E6553.018520
Seidman, I. (2013). Interviewing as qualitative research: A guide for researchers in education \& social sciences (4th Ed.). Teachers College Press.

Sharif, A. M., Kiong, T. T., Zakaria, N. A., \& Salih, M. (2017). Graduates of living skills program of a Malaysian public university: A tracer study. Journal of Asian Vocational Education and Training, 10, 53-64.

Tamuri, A. H., Ismail, M. F., \& Jasmi., K. A (2012). Basic components for Islamic education teacher training. Global Journal Al-Thaqafah, 2(2), 53-63.

Thompson, C. J. (2019). The 'big data' myth and the pitfalls of 'thick data' opportunism: On the need for a different ontology of markets and consumption. Journal of Marketing Management, 35(3-4), 207-230. doi: 10.1080/0267257X.2019.1579751

TVET Division. (2012). Introduction of PTV transformation. Retrieved, October 12, 2019, from http://www.bptv.edu.my/v3/index.php/ transformasi-pendidikan-vokasional.

Yin, R. K. (2014). Case study research: design and methods (5th Ed.). Sage Publications Ins. 
